\title{
BAER-BABINET LAW IN GLACIAL DYNAMICS
}

\author{
Reet KARUKÄPP
}

Geoloogia Instituut (Institute of Geology), Estonia pst. 7, EE-0001 Tallinn, Eesti (Estonia)

Presented by A. Raukas

Received 22 April 1996, accepted 3 June 1996

Abstract. Reconstruction of the glacial dynamics in the southeastern sector of the Scandinavian glaciation demonstrates that the westerly oriented portions of the glacial lobes were more active than the ice lobes of any other direction. The regularity is reflected in the asymmetry of bedrock relief at the margins of glacial lobe depressions and in drumlinized relief within a lobe depression. For discussion the statement that the declination of the glacier towards the right during its movement is due to the Coriolis force and can be explained with the Baer-Babinet law is proposed.

Key words: glacial dynamics, Coriolis force, Scandinavia, Estonia.

\section{INTRODUCTION}

The Coriolis force is known as an apparent force acting on a moving object due to the rotation of the coordinate system in which the object's velocity is measured. It is directed perpendicular to the velocity: to the right in the northern hemisphere and to the left in the southern hemisphere. Gaspard Gustave de Coriolis (1792-1843), the French civil engineer, himself did not apply his theory to any natural process.

Karl Ernst von Baer (1792-1876), an outstanding scientist and the founder of the embryology, was the first to publish his observations on the asymmetry of the river erosion in Russia in 1854 (see Müürsepp, 1984). At that time he was already 62 years old and had not the faintest notion of Coriolis's theory.

Baer ascribed the tendency of erosion of the right bank only to the rivers of meridional direction and was quite convinced that this tendency was not typical of the rivers flowing in the parallel (latitude) direction. 
Jacques Babinet (1794-1872) was the first to formulate (1859) correctly the regularity of river erosion which was based on mathematical calculations and Coriolis's theory (see Müürsepp, 1984). In the course of long-lasting discussions the regularity of formation of river valleys was formulated as the Baer-Babinet law. It is well known that the Coriolis force is also an important factor controlling the direction of ocean streams and atmospheric circulation.

\section{STRUCTURE OF THE CONTINENTAL GLACIER}

Most continental glaciers have a tendency to spread radially and to reach an equilibrium profile. During the Pleistocene this tendency was realized in the form of numerous ice streams with lobes and tongues in their margins.

The structure of the Weichselian glacier is reflected in the topography mainly by alternation of glacial lobe depressions and interlobate deposits. Long-term, in places very profound investigations in the southeastern sector of the Scandinavian glaciation, have provided a large amount of data for detailed reconstruction of local glacier dynamics. The reconstruction of the Gotiglacial stage of deglaciation (Fig. 1) based on the author's investigations and published data (Aseev, 1974; Āboltinš et al., 1976; Znamenskaya et al., 1977; Ekman et al., 1981; Isachenkov, 1981; Punkari, 1993; Dreimanis \& Zelčs, 1995) is time transgressive: the age of the distal part is older than the proximal part and reflects everywhere the last active stage of the glacier lobe (tongue) in the area of its location. A remarkable result of this reconstruction is the demonstration that the westerly oriented portions of the glacial lobes of Gotiglacial time were generally much more active than the ice of any other direction (Fig. 1).

As a rule, the bifurcation of the glacial streams took place in their right side towards the west. For example, the Eastern Latvian and Võru-Hargla lobes branched off from the Peipsi glacial stream and formed a distinct, radially oriented glacial relief (Karukäpp, 1975). The western wing of the Central-Latvian glacier lobe deviated from its main direction by up to $140^{\circ}$ and moved around the Eastern Kursa Upland towards another lobe from the depression of the Baltic Sea (Dreimanis \& Zelčs, 1995). At about the same time (13 000-13 $500 \mathrm{BP}$ ) the western wing of the Baltic ice stream formed a westward moving ice lobe (Low Baltic readvance) in southern Sweden and on the Danish Islands (Ringberg, 1988, 1989).

Ehlers (1990), who described the earlier stages of deglaciation in northwestern Germany, called attention to the tendency of clockwise rotation of the flow lines, however, he did not explain the phenomenon. 


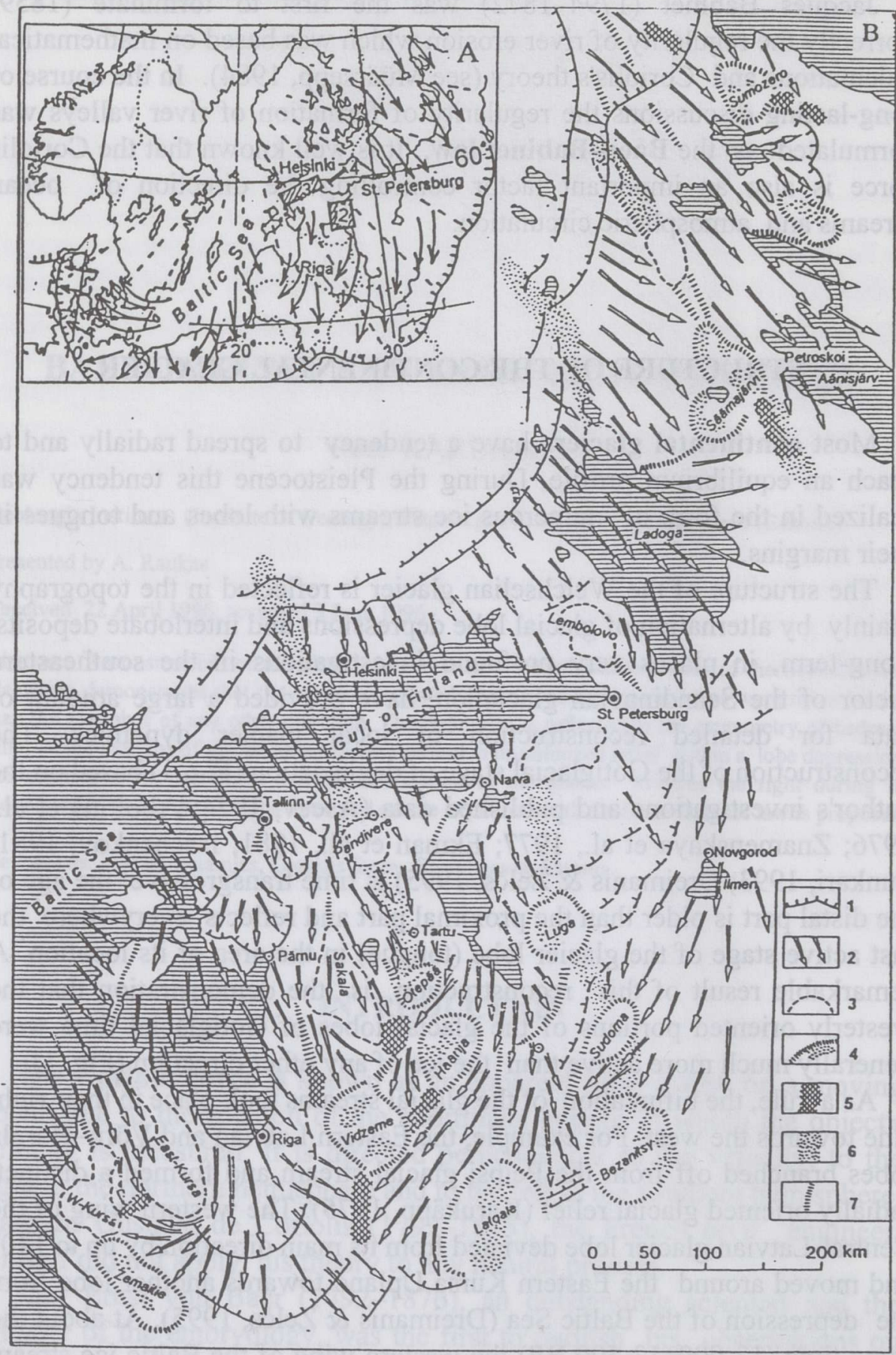

Fig. 1. A. Sketch of dynamics of southern and southeastern parts of the Late Weichselian glacier based on the published data. Dashed lines mark radial orientation, arrows show real direction of ice lobe movement. 2-4, locations of Figs. 2-4.

B. Glacial dynamics and morphogenesis in the southeastern sector of the Scandinavian glaciation in Gotiglacial time. Compiled by R. Karukäpp using published data by O. Āboltinš, J. Straume, I. Ekman, M. Punkari \& V. Isachenkov. 1, glacier margin; 2, ice flow direction at the final stage of its activity; 3, bedrock upland of ice shed; 4, accumulative insular heights; 5 , interlobate complex of landforms; 6 , ice shed between glacier flows; 7 , local ice shed. 
The peripheral cover of the continental ice sheet was considered to have been less than $500 \mathrm{~m}$ thick (Aseev, 1974) and, in all likelihood, the rate of its movement varied from tens to several hundred metres per year. With the thinning of the glacier ice the subglacial surface came to exert an evergrowing effect on the direction of the ice movement. Nevertheless, the detailed investigations in Skåne (Lidmark-Bergström et al., 1991) proved that even big differences (about $250 \mathrm{~m}$ ) in altitudes of the bedrock, oriented perpendicular to the ice movement, did not prevent the ice lobe (Low Baltic Ice) from declining to the right by $140^{\circ}$.

Analysis of the morphology of the lobe depressions in the southeastern sector of the Scandinavian glaciation shows that declination to the right from the radial lines of the ice sheet was typical of the ice streams and lobes in that area. This regularity is particulary clearly revealed by the NE-SW orientation of the local ice divide zones (interlobate formations) (Fig. 1). If the energy of the glacier's movement had been equal radially in all directions, the interlobate formations would have been overwhelmingly of NW-SE orientation.

If glacial streams and lobes tended to ever increasingly deviate to the right, the effect of the glacier (erosion, transport, accumulation) on the lobe depression must have been asymmetric. Let us consider the example of the Peipsi-Pihkva depression (Fig. 2). As a macroform of glacial relief the above depression was relatively small but there are more or less reliable coring data available on its bedrock relief obtained from the land (Tavast \& Raukas, 1982) and on the basis of seismic profiling data from the western part of Lake Peipsi (Noormets et al., in press).

The north-south trending lobe depression in Middle and Upper Devonian sandstones and siltstones measures $50-60 \mathrm{~km}$ in width and 30 $40 \mathrm{~m}$ in depth. Three cross-sections across the depression demonstrate rather clearly differences between the slopes (Fig. 2) which suggest that erosion by glacial streams and lobes was more intensive on the west side. Analysis of the topography of the thoroughly studied Pandivere and Ahtme bedrock uplands (Tavast \& Raukas, 1982) shows that their east slopes are steeper than the west slopes, which also confirms the abovedescribed regularity of glacier dynamics.

The above demonstrates the asymmetry of the dynamics of glacial stream (lobe) as a whole. Let us analyse now glacier dynamics within the glacial stream (lobe) itself, choosing for that purpose the depression of the Gulf of Finland on the east margin of the Baltic glacial stream (Fig. 3). The glacier flow direction is revealed by large drumlin-like forms, up to $90 \mathrm{~m}$ high and $10 \mathrm{~km}$ long. Corings on Prangli Island and indirect (seismic profiling) data concerning the inner structure allow these forms to be classified as predominantly erosional (Kajak et al., 1976; Karukäpp \& Vassiljev, 1992). The cores of the drumlins contain Lower Palaeozoic 

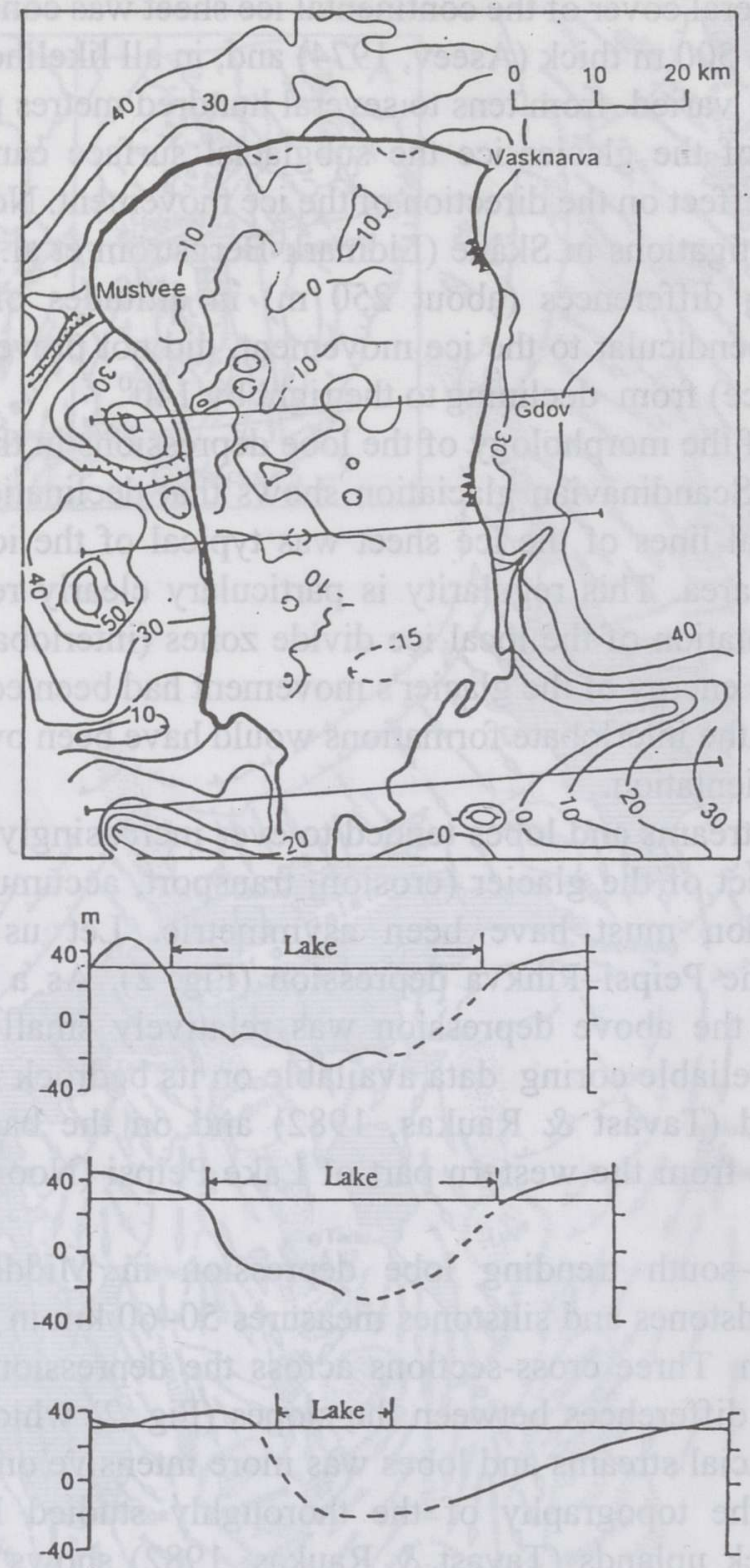

Fig. 2. Bedrock relief of Lake Peipsi depression. Compiled by R. Karukäpp using data by Tavast \& Raukas, 1982 and seismic profiling data (Noormets et al., in press). Isohypses mark height from sea level. Dip of bedrock structure is from north to south. For location see Fig. 1A.

sedimentary bedrock, sediments of earlier glaciations (till), and interglacial deposits (Fig. 3).

In the area under consideration the northeastern slopes of these huge drumlins are somewhat steeper than the southwestern slopes. This seems to support again the above-presented theory according to which erosion by 


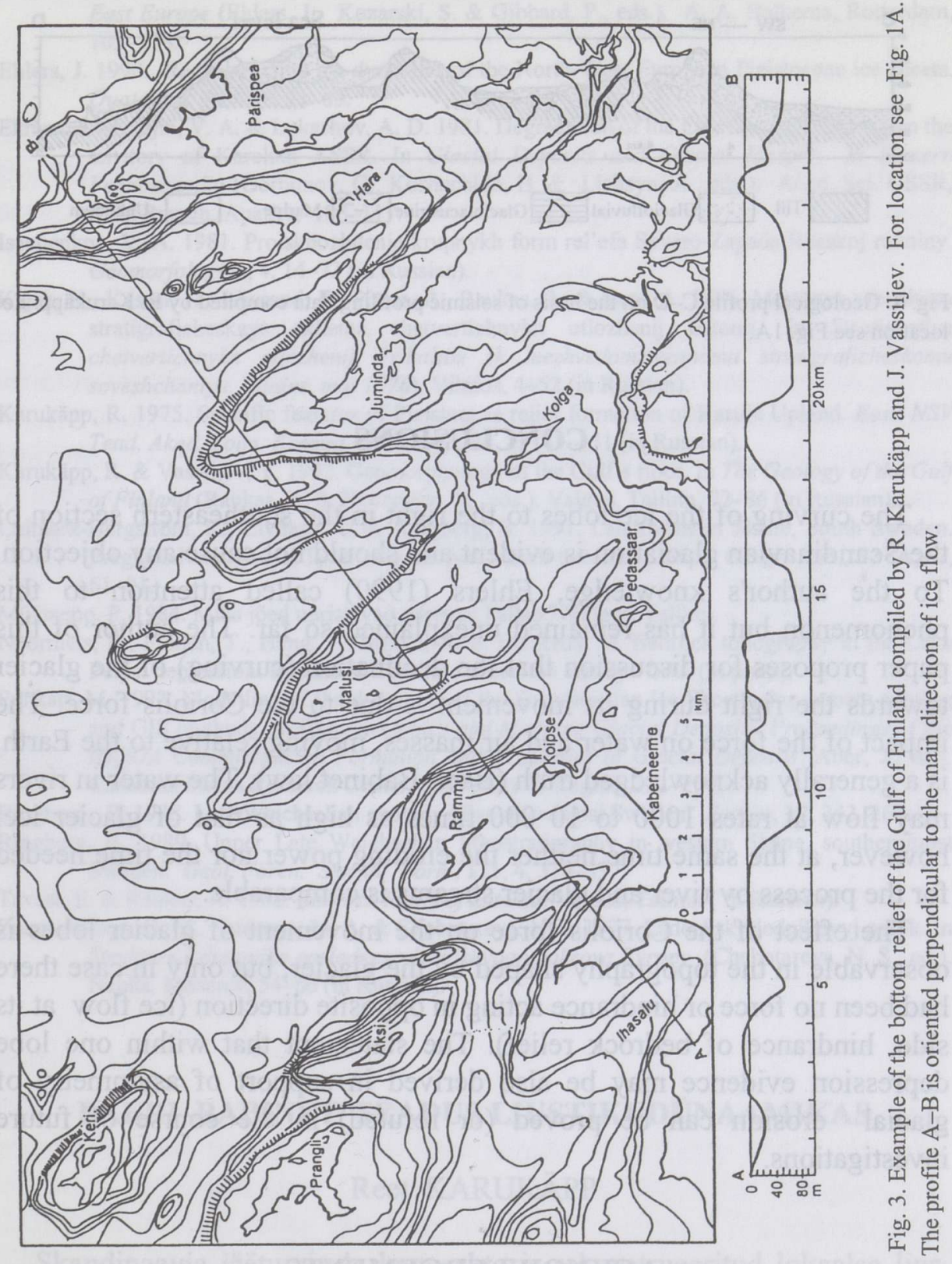


any moving portion of the glacier to the right of its axis is more intensive. The same regularity is revealed in the inclination of the upper surface of till in the geological section compiled on the basis of seismic profiling and directed perpendicular to the direction of the ice movement (Fig. 4).

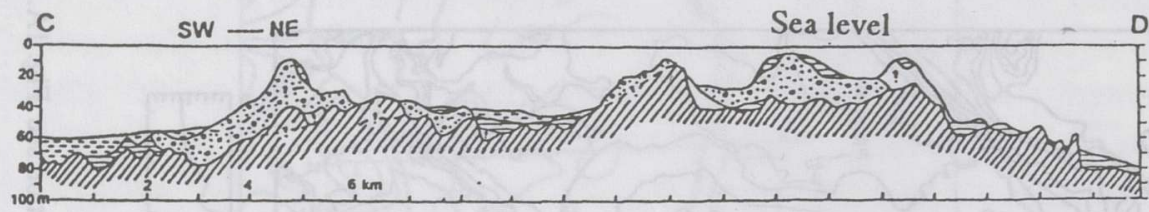

QIIII Till $\because \because$ Glaciofluvial

Fig. 4. Geological profile C-D on the basis of seismic profiling data compiled by R. Karukäpp. For location see Fig. 1A.

\section{CONCLUSIONS}

The curving of the ice lobes to the right in the southeastern section of the Scandinavian glaciation is evident and should not cause any objection. To the author's knowledge, Ehlers (1990) called attention to this phenomenon but it has remained unexplained so far. The author of this paper proposes for discussion that the declination (curving) of the glacier towards the right during its movement is due to the Coriolis force. The impact of the force on water and air masses, moving relative to the Earth, is a generally acknowledged truth (Baer-Babinet law). The water in rivers may flow at rates 1000 to 10000 times as high as that of glacier ice; however, at the same time neither the eroding power nor the time needed for the process by river and glacier streams is comparable.

The effect of the Coriolis force on the movement of glacier lobes is observable in the topography shaped by the glacier, but only in case there had been no force or hindrance acting in opposite direction (ice flow at its side, hindrance of bedrock relief). The statement that within one lobe depression evidence may be also derived in support of asymmetry of glacial erosion can be proved (or refuted) in the course of future investigations.

\section{ACKNOWLEDGEMENTS}

The author is grateful to H. Kukk for linguistic help and to R.Vaher for drawings. The study was partly supported by the Estonian Science Foundation (grant No. 2058). 


\title{
REFERENCES
}

Āboltinš, O. P., Straume, J. A. \& Juškevičs, V. V. 1976. Rel'ef i osnovnye étapy lednikovogo morfogeneza Aluksnenskoj vozvyshennosti. In Voprosy chetvertichnoj geologii. Vyp. 9 (Danilāns, S., ed.). Zinatne, Riga, 79-89 (in Russian).

Aseev, A. A. 1974. Drevnie materikovye oledeneniya Evropy. Nauka, Moscow (in Russian).

Dreimanis, A. \& Zelčs, V. 1995. Pleistocene stratigraphy of Latvia. In Glacial Deposits in NorthEast Europe (Ehlers, J., Kozarski, S. \& Gibbard, P., eds.). A. A. Balkema, Rotterdam, $105-114$.

Ehlers, J. 1990. Reconstructing the dynamics of the North-West European Pleistocene ice sheets. Quat. Sci. Rev., 9, 71-83.

Ekman, I. M., Iljin, V. A. \& Lukashov, A. D. 1981. Degradation of the Late Glacial ice sheet on the territory of Karelian ASSR. In Glacial Deposits and Glacial History in Eastern Fennoscandia (Gorbunov, G., Koshechkin, B. \& Lisitsyn, A., eds.). Acad. Sci. USSR, Kola Branch, Apatity, 103-117.

Isachenkov, V. A. 1981. Proiskhozhdenie krupnykh form rel'efa Severo-Zapada Russkoj ravniny. Geomorfologiya, 4, 14-73 (in Russian).

Kajak, K., Kessel, H., Liivrand, E., Pirrus, R., Raukas, A. \& Sarv, A. 1976. Mestnaya rabochaya stratigraficheskaya skhema chetvertichnykh otlozhenij Estonii. In Stratigrafiya chetvertichnykh otlozhenij Pribaltiki ( $k$ mezhvedomstvennomu stratigraficheskomu soveshchaniyu. Vilnius, mai 1976). Vilnius, 4-52 (in Russian).

Karukäpp, R. 1975. Specific features of Pleistocene relief formation of Karula Upland. Eesti NSV Tead. Akad. Toim. Keemia. Geoloogia, 24, 2, 145-151 (in Russian).

Karukäpp, R. \& Vassiljev, Y. 1992. Geomorphology of the Gulf's floor. In The Geology of the Gulf of Finland (Raukas, A. \& Hyvarinen, H., eds.). Valgus, Tallinn, 72-86 (in Russian).

Lidmark-Bergström, K., Elvhage, C. \& Ringberg, B. 1991. Landforms in Skåne, South Sweden. Preglacial and glacial landforms analysed from two relief maps. Geogr. Ann., 73 (A), 2, 61-91.

Müürsepp, P. 1984. Miks jõed uuristavad paremat kallast? Valgus, Tallinn.

Noormets, R., Floden, T., Hang, T., Miidel, A. \& Bjerkeus, M. Bedrock topography in the Lake Peipsi depression: Results of a seismic reflection survey. GFF (in press).

Punkari, M. 1993. Modelling of the dynamics of the Scandinavian Ice Sheet using remote sensing and GIS methods. In Glaciotectonics and Mapping Glacial Deposits. Proceedings of the INQUA Commission on Formation and Properties of Glacial Deposits (Aber, J., ed.). Canadian Plains Research Center, University of Regina, 232-250.

Ringberg, B. 1988. Late Weichselian geology of southernmost Sweden. Boreas, 17, 243-263.

Ringberg, B. 1989. Upper Late Weichselian lithostratigraphy in western Skåne, southernmost Sweden. Geol. Fören. Stockh. Förh., 111, 4, 319-337.

Tavast, E. \& Raukas, A. 1982. Bedrock Relief of Estonia. Valgus, Tallinn (in Russian).

Znamenskaya, O. M., Faustova, M. A. \& Chebotareva, N. S. 1977. Ladozhskij lednikovyj potok. In Struktura i dinamika poslednego lednikovogo pokrova Evropy (Chebotareva, N. S., ed.). Nauka, Moscow, 54-66 (in Russian).

\section{BAERI-BABINET' SEADUS LIUSTIKUDÜNAAMIKAS}

\author{
Reet KARUKÄPP
}

Skandinaavia jäätumisala kagusektoris rekonstrueeritud lokaalse liustiku liikumissuundade alusel ilmneb, et liustikuvooludel ja -keeltel oli tendents kalduda liikumisel telgjoonest paremale. Parempoolses liustikuvoolu (-keele) osas on ka eksaratsioon olnud intensiivsem. Seda näitab keelenõo ebasümmeetria. Esialgsetel andmetel on liustiku kulutuse ebasümmeetria 
täheldatav ka keelenõo piires voorestatud pinnamoe nõlvakallete erinevustena.

Liustiku kaldumist liikumisel paremale (lääne suunas) ning pinnamoe kujunemise ebasümmeetriat põhjendatakse Coriolisi jõu mõjuga liikuvale liustikule vastavalt Baeri-Babinet' seadusele, mille järgi jõgi (õhumass, merehoovus) kaldub põhjapoolkeral liikumise esialgsest suunast paremale, lõunapoolkeral vasakule.

\section{ЗАКОН БЭРА-БАБИНЭ В ЛЕДНИКОВОЙ ДИНАМИКЕ}

\section{Реэт КАРУКЯПП}

Реконструкция направлений движения ледника в юго-восточном секторе скандинавского оледенения демонстрирует его явное отклонение вправо от оси ледниковых потоков и языков. Асимметрия проявляется также в ледниковой экзарации склонов лопастной депрессии, где западные склоны круче восточных. Предварительные наблюдения позволяют предполагать асимметрию и менее масштабных форм, к примеру склонов экзарационных друмлинов.

Отклонение движения ледника направо (на запад) происходит под влиянием ускорения Кориолиса и объясняется законом БэраБабинэ, согласно которому в Северном полушарии водные и воздушные потоки отклоняются от первоначального направления вправо, а в Южном полушарии - влево. 